\title{
Quantitative Research Regarding the Impact of Amending the VAT Legislation on the Business Environment and on the Population
}

\author{
Ec. George-Adrian STANCIU
}

Vrancea, Romania

\begin{abstract}
This paper is based on quantitative research regarding the impact of amending the VAT legislation on the business environment and on the population, illustrates the methodology behind the research, analysis and interpretation of results, and determines the main objectives and assumptions of the research. This paper is intended mainly for economic agents, as we considered it to be quite important, being useful both in the current economy and future economy. In order for the economy to develop from several points of view (extensively, intensively), tax consultants but also economic agents should approach and analyze in a deeper way their preferences and desires.
\end{abstract}

Key terms: value added tax, VAT rates, VAT cash accounting system, taxpayers, legislative changes JEL Classification: K34, H87

To cite this article: George-Adrian Stanciu, Quantitative Research Regarding the Impact of Amending the VAT Legislation on the Business Environment and on the Population, CECCAR Business Review, No 2/2021, pp. 53-63, DOI: http://dx.doi. org/10.37945/cbr.2021.02.06

\section{The evolution of VAT rates at EU level}

The knowledge of this tax worldwide, being initially adopted in France, has developed in various countries in Europe, Latin America, Africa. The application and structure of the value added tax rate differs from country to country, as the vast majority of countries implement at least two rates, sometimes even three: a standard rate and two reduced rates.

Over time, value added tax has undergone various changes in terms of percentage rates applicable to taxable transactions but also the composition of the tax base, taxable persons, taxable transactions, supporting documents, exempt transactions that benefited from the deduction but also those that did not. All these changes had an impact on economic agents in particular, as well as on the population, on the consumer prices which require a detailed analysis before their application.

The table below lists the VAT rates applicable at European Union level.

Table 1. The VAT rates applicable at European Union level

\begin{tabular}{|c|c|c|c|}
\hline Member State & Super-reduced VAT rate & Reduced VAT rate & Standard VAT rate \\
\hline Hungary & - & $5 / 18$ & 27 \\
\hline Croatia & - & $5 / 13$ & 25 \\
\hline Denmark & - & - & 25 \\
\hline Sweden & - & $6 / 12$ & 25 \\
\hline Finland & - & $10 / 14$ & 24 \\
\hline
\end{tabular}




\begin{tabular}{|c|c|c|c|}
\hline Member State & Super-reduced VAT rate & Reduced VAT rate & Standard VAT rate \\
\hline Greece & - & $6 / 13$ & 24 \\
\hline Ireland & 4.8 & 9/13.5 & 23 \\
\hline Poland & - & $5 / 8$ & 23 \\
\hline Portugal & - & $6 / 13$ & 23 \\
\hline Italy & 4 & $5 / 10$ & 22 \\
\hline Slovenia & - & 9.5 & 22 \\
\hline Belgium & - & $6 / 12$ & 21 \\
\hline Czech Republic & - & $10 / 15$ & 21 \\
\hline Latvia & - & 12 & 21 \\
\hline Lithuania & - & $5 / 9$ & 21 \\
\hline Netherlands & - & 6 & 21 \\
\hline Spain & 4 & 10 & 21 \\
\hline Austria & - & $10 / 13$ & 20 \\
\hline Bulgaria & - & 9 & 20 \\
\hline Estonia & - & 9 & 20 \\
\hline France & 2.1 & $5.5 / 10$ & 20 \\
\hline Great Britain & - & 5 & 20 \\
\hline Slovakia & - & 10 & 20 \\
\hline Cyprus & - & $5 / 9$ & 19 \\
\hline Germany & - & 7 & 19 \\
\hline Romania & - & $5 / 9$ & 19 \\
\hline Malta & - & $5 / 7$ & 18 \\
\hline Luxembourg & 3 & 8 & 17 \\
\hline
\end{tabular}

Source: Author's contribution.

Hereinafter, we will present some particular cases regarding the application of VAT at the level of the European Union.

Table 2. Characteristics of member countries

\begin{tabular}{|c|l|}
\hline Country & \multicolumn{1}{c|}{ Characteristics } \\
\hline Belgium & $\begin{array}{l}\text { Application of the fixed rate system - only in the case of small enterprises that mainly } \\
\text { carry out relationships with small private individuals and whose turnover does not exceed } \\
500,000 \text { EUR. The determination of the fixed VAT rate is made according to the turnover. } \\
\text { Tax exemption system - applicable for companies that exceed the turnover of } \\
500,000 \text { EUR - not having the right to deduct VAT for purchases made. }\end{array}$ \\
\hline Germany & $\begin{array}{l}\text { Moderate quotas are used for companies operating in the fields of agriculture and } \\
\text { forestry. There are situations in which, if the turnover does not exceed 15,000 EUR, } \\
\text { they can waive the payment of this tax. The submission of VAT statements, of } \\
\text { the calculation of the profit tax has as deadline the 31 } 31^{\text {st }} \text { of May. In situations where } \\
\text { companies are represented by a tax consultant, a lawyer or a certified accountant, } \\
\text { they have the possibility to extend the period for the submission of statements. }\end{array}$ \\
\hline
\end{tabular}




\begin{tabular}{|c|c|}
\hline Country & Characteristics \\
\hline & $\begin{array}{l}\text { This deferral can be an advantage for companies, as deferring taxes and duties would be } \\
\text { an additional source of cash. As of } 1 \text { January } 2007 \text {, Germany applies a standard rate } \\
\text { of } 19 \% \text { and } 7 \% \text { only for portion of the foodstuffs and public transport. The tax exemption } \\
\text { applies to some services, such as rental or medical services. }\end{array}$ \\
\hline Denmark & $\begin{array}{l}\text { It is one of the countries with the highest VAT rate in the entire European Union (25\%), } \\
\text { except for newspapers, which are taxed at 0\% VAT. }\end{array}$ \\
\hline Finland & $\begin{array}{l}\text { The sale of second-hand goods and the provision of services by travel agencies benefit } \\
\text { from a special VAT regime, similar to that in Romania. }\end{array}$ \\
\hline Hungary & $\begin{array}{l}\text { Value added tax reaches the highest level in the European Union. It fluctuated in July } \\
2009 \text {, from } 20 \% \text { to } 25 \% \text {, reaching the standard rate of } 27 \% \text { in } 2012 \text {. The reduced rate } \\
\text { of } 18 \% \text { is used for some food products but also for accommodation services. Heating } \\
\text { services were taxed at } 18 \% \text { in } 2009 \text {, decreasing to } 5 \% \text { in } 2010 \text {. The VAT rate also applies } \\
\text { to medicine, books and newspapers. }\end{array}$ \\
\hline Great Britain & $\begin{array}{l}\text { The standard share of value added tax increased in } 2011 \text { from } 17.5 \% \text { to } 20 \% \text {. The reduced } \\
\text { rate of } 5 \% \text { was applicable to fuel and energy, and a small number of categories were } \\
\text { taxed at } 0 \% \text {. }\end{array}$ \\
\hline France & $\begin{array}{l}\text { It currently benefits from a VAT rate of } 20 \% \text {, starting from a level of } 19.6 \% \text { to } 21.2 \% \\
\text { in } 2012 . \text { In the case of basic goods, the rate of } 5.5 \% \text { is used, } 7 \% \text { for real estate, } \\
\text { accommodation and restaurant services, and } 2.1 \% \text { for newspapers, theaters and medicine. }\end{array}$ \\
\hline
\end{tabular}

Source: The data based on which the comparisons between the different states and Romania were made were taken from the European Union portal.

For example, in Italy, the VAT rate used for medicines is $4 \%$, compared to $9 \%$, the VAT rate applied in Romania. In Austria, the median quota of $16 \%$ is used for the Junghols and Mittelberg areas, in the case of rents the quota of $10 \%$ applies, and for agricultural activities moderate quotas apply (http://discutii.mfinante.ro/ static/10/Mfp/trezorerie/sisteme_imp_UE_directe_indir_contributii.pdf).

\section{O Research methodology}

The aim of the empirical research conducted is to find out the perception of the business environment and of the population regarding the legislative changes in the field of value added tax that took place in Romania.

The data collection was done through a survey containing a set of questions and is structured in two parts not highlighted separately in it. The first part of the survey contains demographic information about respondents (gender, the type of entity in which they work, the entity's field of activity, professional experience), while the second part aimed to obtain information on the perception of changes in tax legislation on added value.

The legislative changes that have been the subject of this survey relate to the VAT cash accounting system, VAT rates, reverse charge and taxpayers' declaratory obligations. Regarding the VAT cash accounting system, the survey aimed to establish the effects of the introduction of this system, as well as the perception on its transition from a mandatory system to an optional one.

The change in the value added tax rates (decrease of the standard rate from $24 \%$ to $19 \%, 5 \%$ taxation of certain activities that were previously taxed by $9 \%$ ) was the subject of several questions in the questionnaire, which aimed to identify the benefits for taxpayers, but also for the state, as well as their influence on prices.

Also, other proposed objectives of the survey were as follows:

- frequency of legislative changes;

- ways of informing the population about the legislative changes regarding VAT; 
- ways to update accounting systems;

- determining the consequences following legislative changes.

The research took place both in Bucharest and in provincial areas and was based on a questionnaire. It was filled out by 60 persons who are professional accountants working in companies from various fields and have professional experience and by students, in which case it enabled them to understand the aspects of value added tax. The period in which the research was conducted was 1-15 May 2020 and the questionnaire could be filled out online, at http://www.isondaje.ro/.

In this paper, the sample that we refer to is 60 respondents, taking part in an exploratory research. We chose to use the stratified random method as a sampling method: going out from the premise that the legislative changes on VAT have impacted both the business environment and the economic situation in terms of population.

\section{Analysis and interpretation of results}

Next, we will present the results of the 60 respondents in detail, in order to determine the main purpose of this paper, both for each question and through correlations between them. All the figures and tables presented below represent the author's projection based on the answers to the questionnaire.

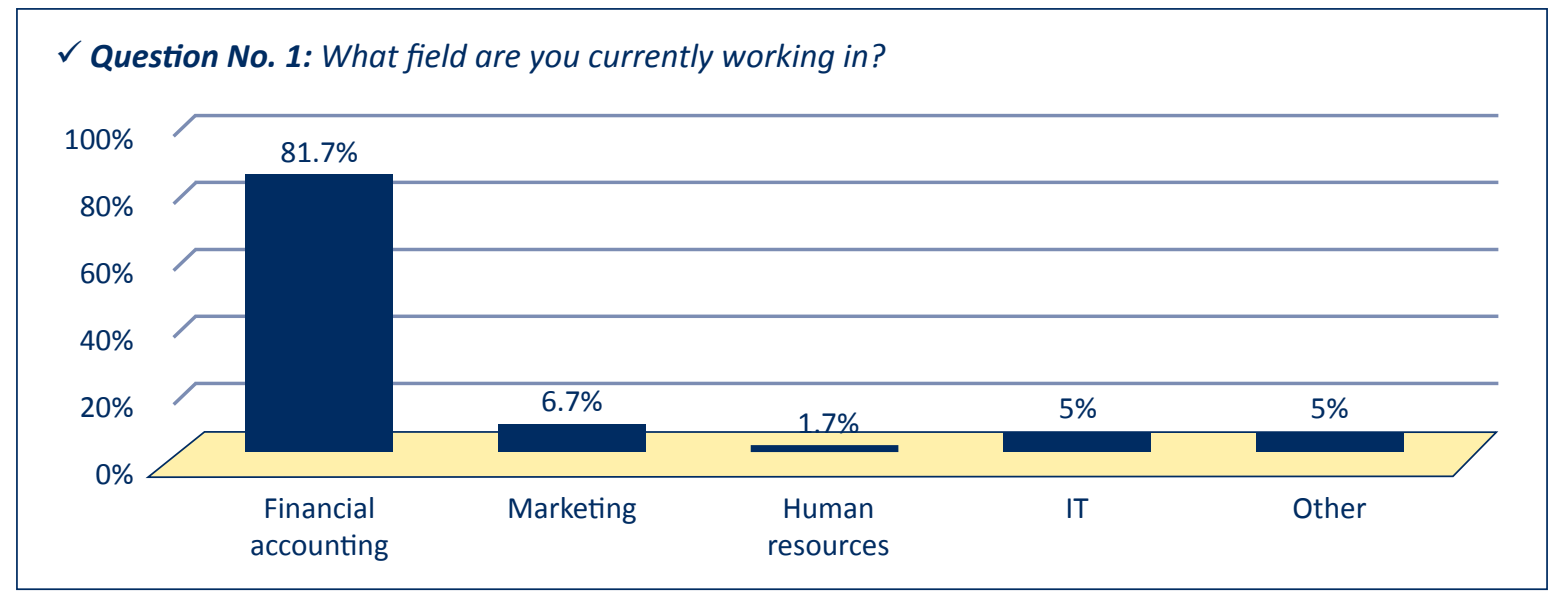

Figure 1. Field of activity

The vast majority of respondents work in the financial-accounting field, in a proportion of $81.7 \%$, the difference up to $100 \%$ being made up of people working in fields such as marketing, tax and IT.

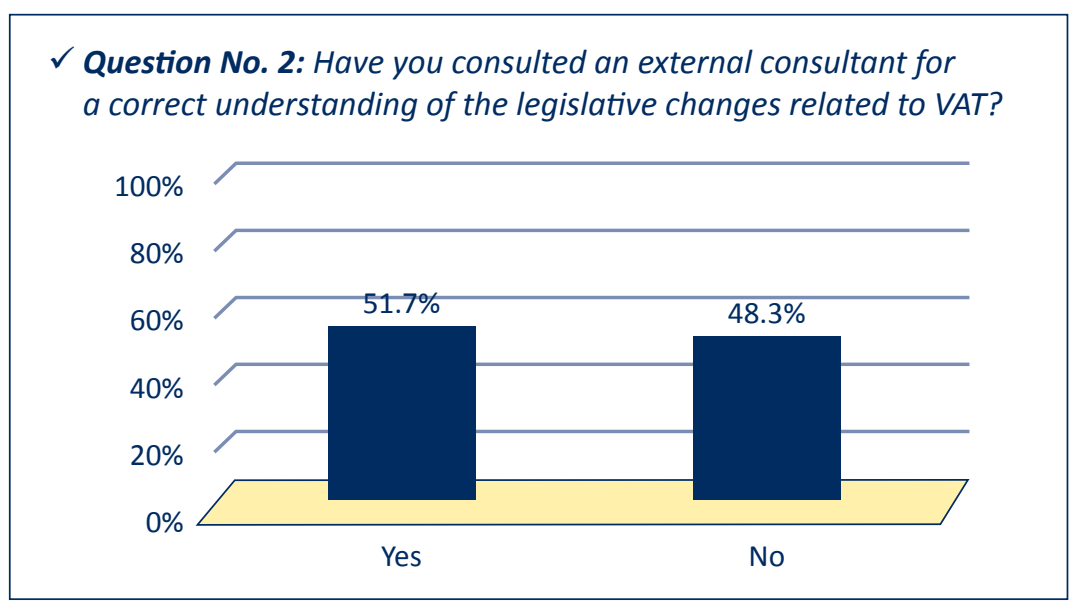

Figure 2. Contact a tax consultant - legislative changes 
According to this question, $51.7 \%$ of respondents turned to a tax consultant to ensure that their understanding of the changes in legislation is correct and that they are not subject to any tax risk. As a rule, the opinion of tax consultants is much more appreciated than the appeal to the Fiscal Code, as the specified laws always leave room for interpretation.

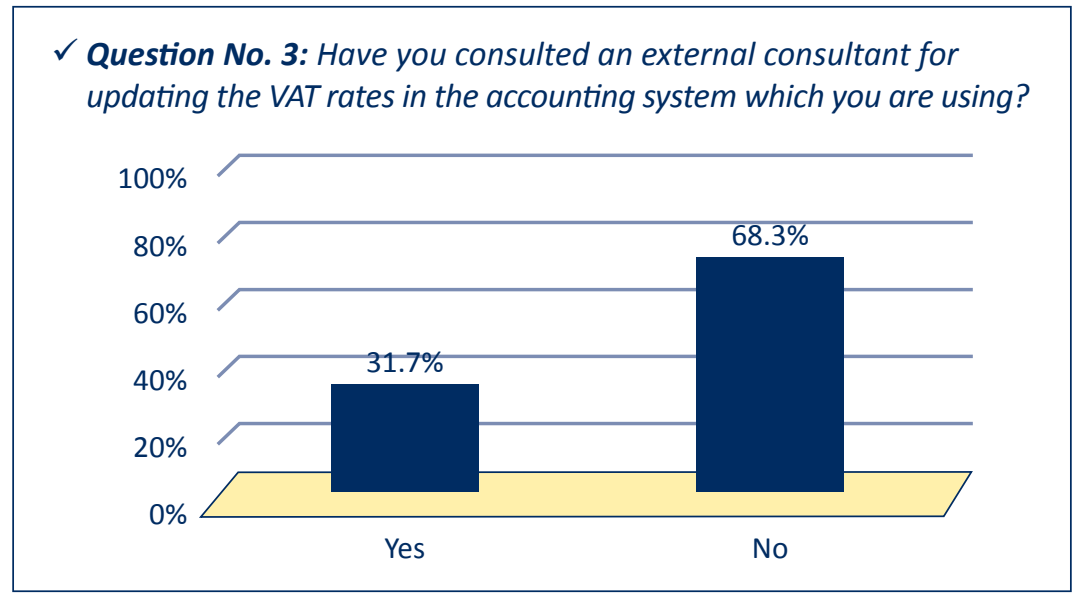

Figure 3. Contact a tax consultant - VAT rates

As can be seen in Figure 3,68.3\% of respondents considered that the assistance of a tax consultant is not necessary to update VAT rates in the accounting systems they use. We consider that this action does not require the presence of a consultant, as most companies organize various in-house trainings to develop these skills.

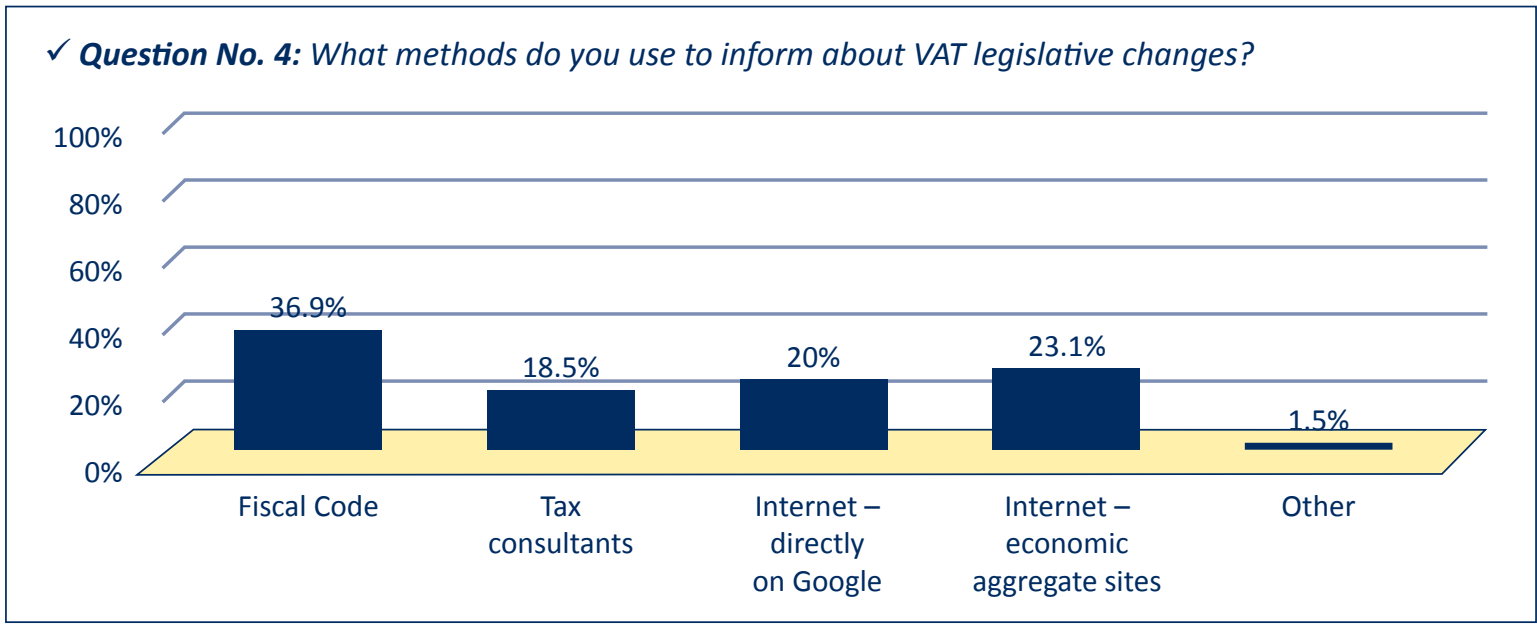

Figure 4. Methods used for information

For this question, the answer with the highest percentage is the Fiscal Code. At a difference of about 14\%, $23.1 \%$ of respondents opt for the most easily accessible source, namely the Internet - through economically aggregated sites. Most companies subscribe to various sources of information, thus receiving newsletters in electronic format from these sites. Two of the respondents chose another option, namely television and tax conferences.

As can be seen in Figure 5, a percentage of $48.3 \%$ respondents stated that the operational activity of the company in which they work was affected at a medium, moderate level. A lower percentage of $3.3 \%$ of the 60 respondents consider that the operational activity was affected in very large proportions. 


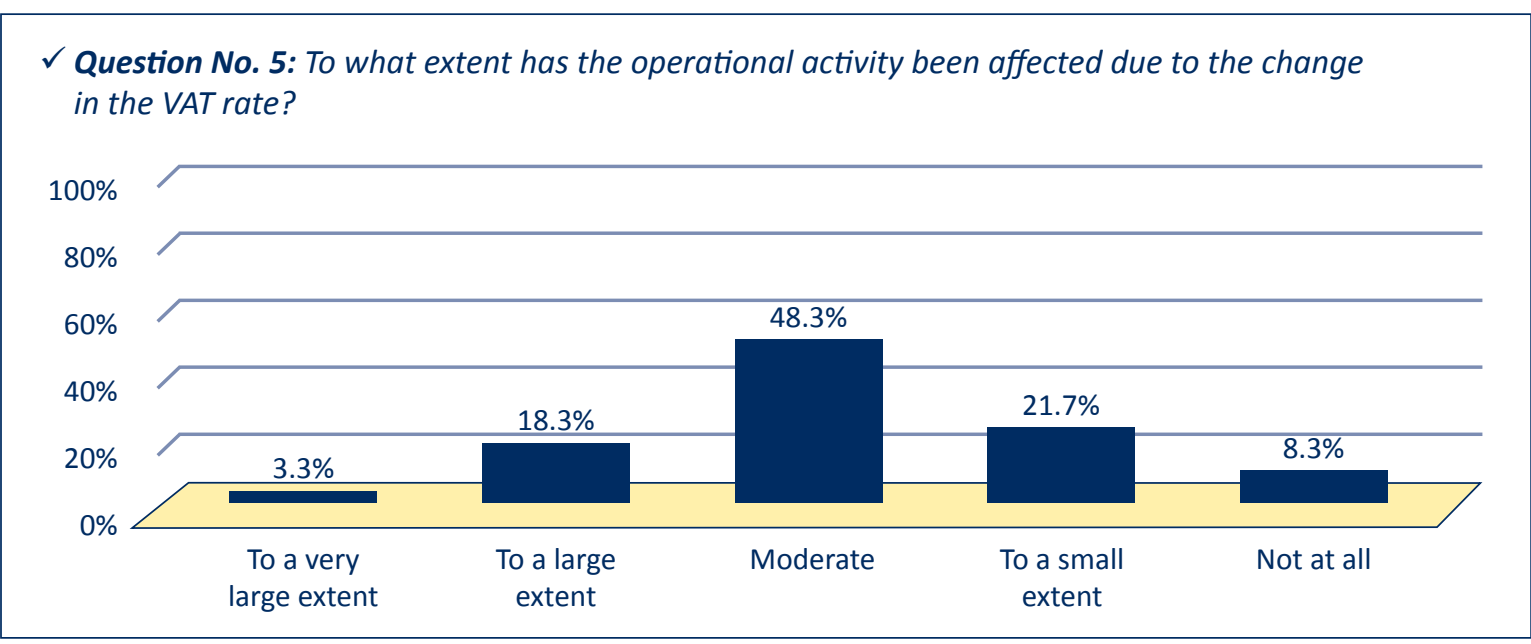

Figure 5. Impact on operational activity

$\checkmark$ Question No. 6: Please rate the following risks from 1 to 5, taking into account the negative effect of the changes in the VAT rate on economic activity (1 - not important; 5 -very important).

As can be seen in the table below, $20 \%$ of respondents consider that the risk of making interest payments and penalties in case of not collecting the correct VAT rate has a very high impact. Even if it has the largest share, for $8.3 \%$ of respondents they are not important at all.

On the other hand, the possibility of tax non-deductibility in case of non-compliance with the amended legislation and transitional provisions and the risk of litigation insofar as the VAT provisions are unclear in contracts with third parties are considered in proportions of $31.7 \%$ and $30 \%$ of respondents, respectively, only important.

Table 3. The negative effect of the VAT change

\begin{tabular}{|l|c|c|c|c|c|}
\hline & $\mathbf{1}$ & $\mathbf{2}$ & $\mathbf{3}$ & $\mathbf{4}$ & $\mathbf{5}$ \\
\hline $\begin{array}{l}\text { Risk of interest and penalties in case of not collecting } \\
\text { the correct VAT rate }\end{array}$ & 8.3 & 15 & 36.7 & 20 & 20 \\
\hline $\begin{array}{l}\text { Risk of increased costs with adapting software in case } \\
\text { the implementation occurred too late }\end{array}$ & 10 & 21.7 & 36.7 & 23.3 & 8.3 \\
\hline $\begin{array}{l}\text { The risk of losing customers to the extent that price lists } \\
\text { have not been updated in a timely manner }\end{array}$ & 21.7 & 13.3 & 26.7 & 25 & 13.3 \\
\hline $\begin{array}{l}\text { Possibility of tax non-deductibility in case of } \\
\text { non-compliance with the ammended legislation and } \\
\text { transitional provisions }\end{array}$ & 8.3 & 10 & 33.3 & 31.7 & 16.7 \\
\hline $\begin{array}{l}\text { Risk of engaging unnecessary sources of funding to the } \\
\text { extent that the liquidity budget is not properly calculated }\end{array}$ & 13.3 & 20 & 36.7 & 26.7 & 3.3 \\
\hline $\begin{array}{l}\text { Risk of litigation to the extent that the VAT provisions are } \\
\text { unclear in contracts with third parties }\end{array}$ & 10 & 21.7 & 28.3 & 30 & 10 \\
\hline
\end{tabular}

$\checkmark$ Question No. 7: Rate the following consequences from 1 to 5, taking into account the positive effect of the changes in the VAT rate on economic activity (1 - not important; 5 -very important). 
Table 4. The positive effect of the VAT change

\begin{tabular}{|l|c|c|c|c|c|}
\hline & $\mathbf{1}$ & $\mathbf{2}$ & $\mathbf{3}$ & $\mathbf{4}$ & $\mathbf{5}$ \\
\hline $\begin{array}{l}\text { Stimulating the consumption of products/services } \\
\text { by decreasing sales prices }\end{array}$ & 18.3 & 16.7 & 23.3 & 26.7 & 15 \\
\hline $\begin{array}{l}\text { Better standard of living, due to increased consumption } \\
\text { of goods and services }\end{array}$ & 10 & 23.3 & 38.3 & 25 & 3.3 \\
\hline Decreasing the level of taxes paid to the state & 15 & 13.3 & 25 & 35 & 11.7 \\
\hline Attractive environment for foreign investors & 18.3 & 8.3 & 31.7 & 31.7 & 10 \\
\hline
\end{tabular}

Regarding the positive effects of the VAT rate change, it is easy to see that they have a much lower share than the negative effects. The majority of respondents consider that the most important aspect is the stimulation of the consumption of products/services by decreasing the sales prices, in a proportion of $15 \%$, in the second place being the decrease in the level of taxes paid to the state, with a percentage of $11.7 \%$. Also, $38.3 \%$ of the 60 respondents state that the change in VAT rates helps to develop a better standard of living, due to the increased consumption of goods and services.

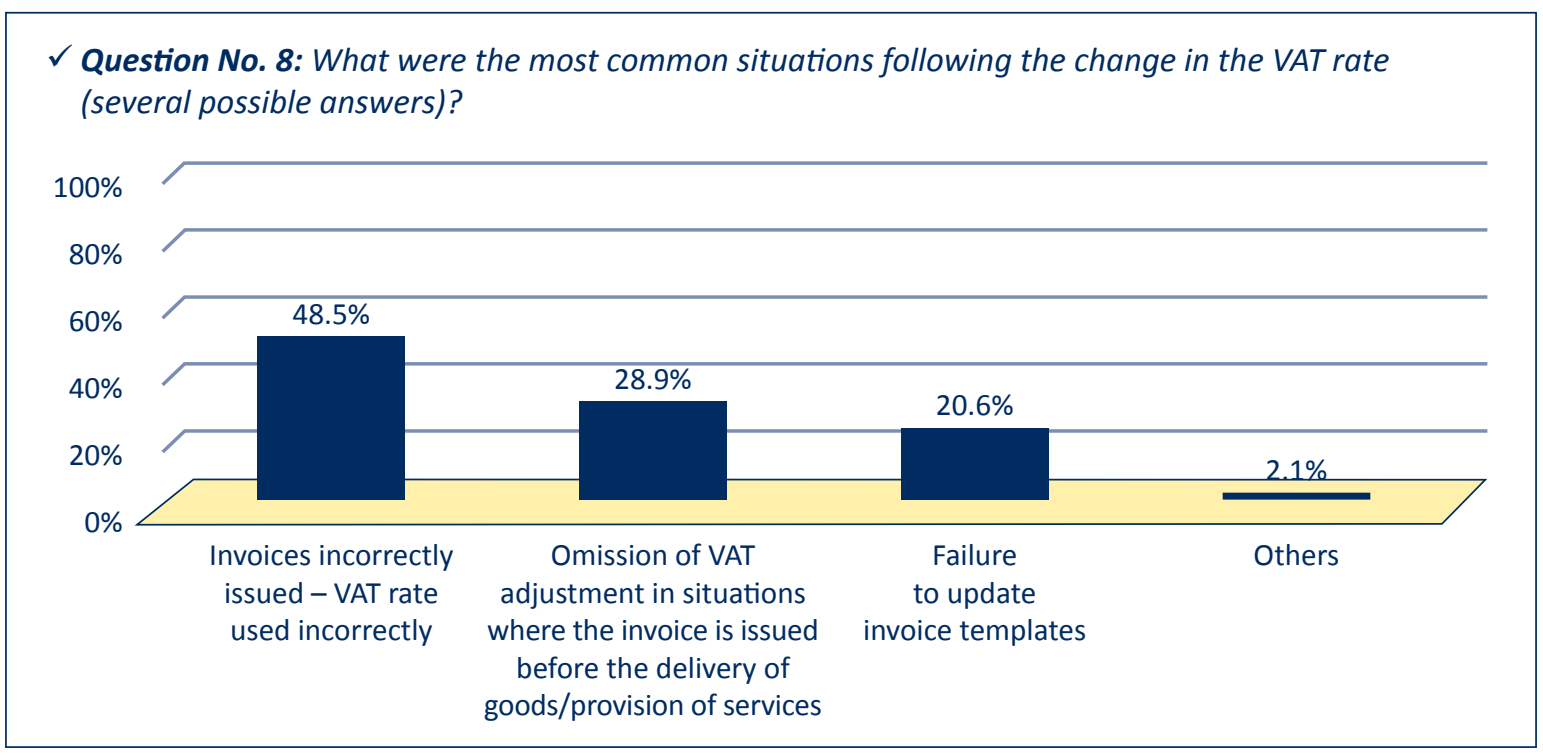

Figure 6. Situations encountered following the change of the VAT rate

To this question, a majority of $48.5 \%$ of the participants answered that the most frequent situations encountered after the change of the VAT rate consisted in the incorrect preparation of fiscal invoices, by using an inadequate VAT rate. Next, with a percentage of $28.9 \%$, is the omission of the VAT adjustment in situations where the invoice is issued before the delivery of goods/provision of services. Usually, this situation occurs when, at the end of the year, the fiscal invoice is issued, and in the following year, when the legislative changes occur and at the same time the delivery of goods/provision of services takes place, the taxpayer loses sight of this aspect, and the VAT value is no longer adjusted.

Two of the 60 respondents stated that despite the fact that the VAT rates have changed, the total they pay for the purchase of a good/service remains unchanged because only the price increase took place. 


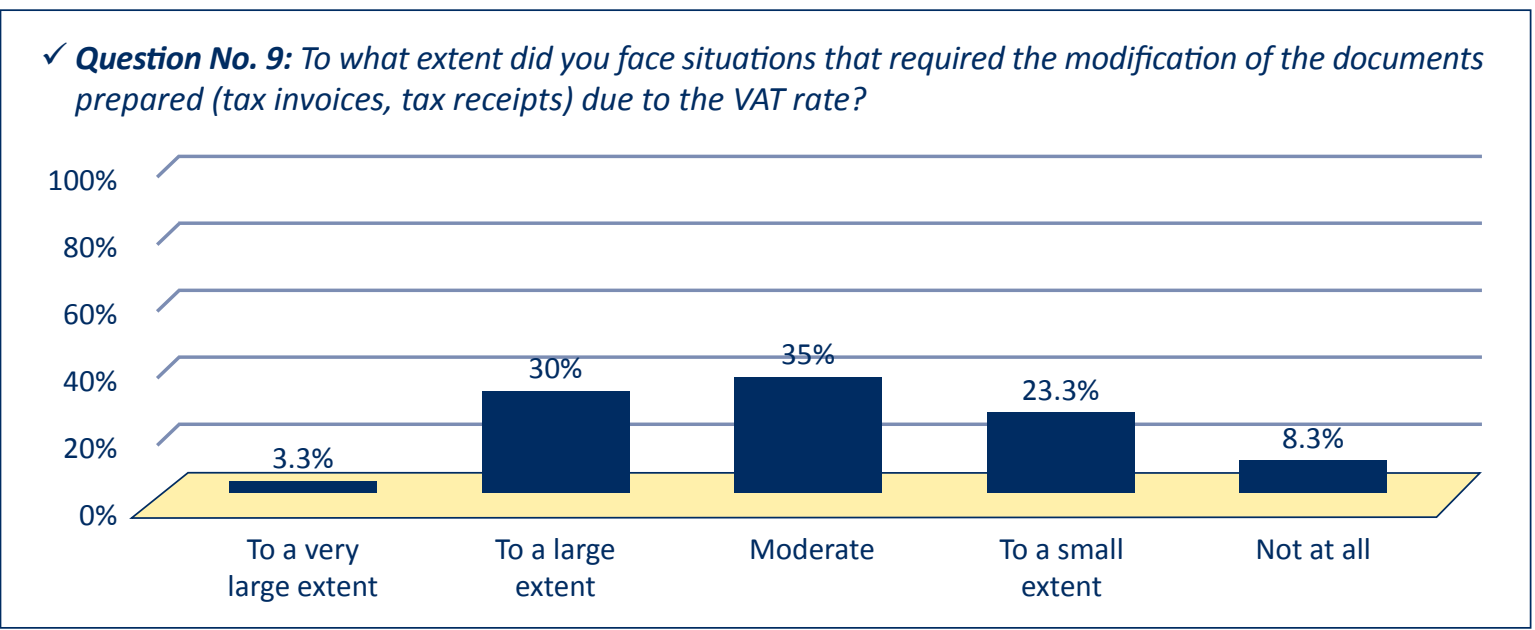

Figure 7. Degree of modification of documents

According to the data provided in the graph above, the companies faced an average level of situations in which the documents received needed updating due to the VAT rate, in a proportion of $35 \%$, and a proportion of $8.3 \%$ did not encounter such situations.

$\checkmark$ Question No. 10: To what extent do you agree with the following VAT claims?

Table 5. Agreement on VAT claims

$-\%-$

\begin{tabular}{|l|c|c|c|c|c|}
\hline & $\begin{array}{c}\text { Strongly } \\
\text { agree }\end{array}$ & Agree & Indifferent & Disagree & $\begin{array}{c}\text { Strongly } \\
\text { disagree }\end{array}$ \\
\hline $\begin{array}{l}\text { In Romania there is no system that enables the } \\
\text { verifications of transactions falling within the } \\
\text { scope of VAT at national and international levels. }\end{array}$ & 11.7 & 43.3 & 21.7 & 20 & 3.3 \\
\hline $\begin{array}{l}\text { The elimination of the obligation to register } \\
\text { companies in the Register of Intra-Community } \\
\text { Operators is an advantage for taxpayers paying } \\
\text { VAT. }\end{array}$ & 30 & 18.3 & 38.3 & 10 & 3.3 \\
\hline $\begin{array}{l}\text { The registration operation for VAT purposes } \\
\text { is a complex process in Romania compared } \\
\text { to the rest of the member countries. }\end{array}$ & 36.7 & 38.3 & 13.3 & 11.7 & 0 \\
\hline $\begin{array}{l}\text { VAT-paying companies have more benefits } \\
\text { than non-VAT companies. }\end{array}$ & 8.3 & 28.3 & 43.3 & 18.3 & 1.7 \\
\hline
\end{tabular}

Regarding the statement on the lack of a system developed to verify transactions falling within the scope of VAT, $43.3 \%$ of respondents agreed. The systems available to the Romanian authorities are not sufficiently developed for in-depth checks. The majority of respondents (38.3\%) expressed their indifference regarding the elimination of the obligation to register companies in ROI (Register of Intra-Community Operators) for VAT-paying companies, closely followed by the total agreement of $30 \%$ of the questioned persons. We consider this change to be an advantage for VAT-paying taxpayers, as it eliminates the entire registration process and the preparation of related documentation, so that intra-Community acquisitions can be made more easily.

Regarding the registration operation for VAT purposes in Romania, 38.3\% of the participants agree that the process is of a much greater complexity, compared to the member countries. At the same time, this statement 
obtained the full agreement of $36.7 \%$ of respondents. Regarding the benefits of a VAT-paying company, $43.3 \%$ expressed indifference, and $28.3 \%$ agreed that this category of companies has several advantages (lower expenses).

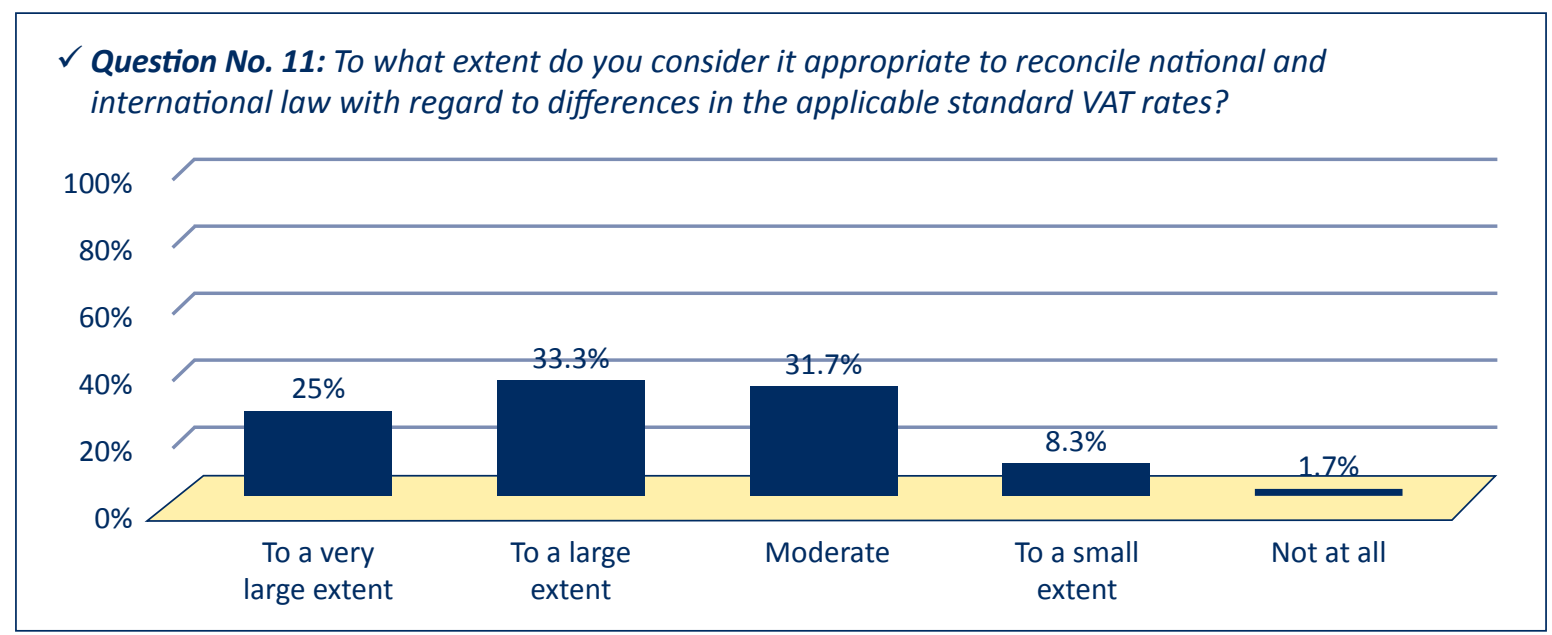

Figure 8. Reconciling national and international law

Out of the 60 respondents, $33.3 \%$ consider that the reconciliation of national and international legislation is largely appropriate. We believe that its usefulness lies in identifying discrepancies at the level of each country and the possibility of adapting or correcting them, as appropriate.

$\checkmark$ Question No. 12: Have you been in the situation in which the company that you work for/manage is a company that does not pay VAT?

For this question, the majority of respondents stated in a proportion of $66.7 \%$ that the companies for which they work (71.7\% having an executive position and $28.3 \%$ a management position) were not paying VAT.

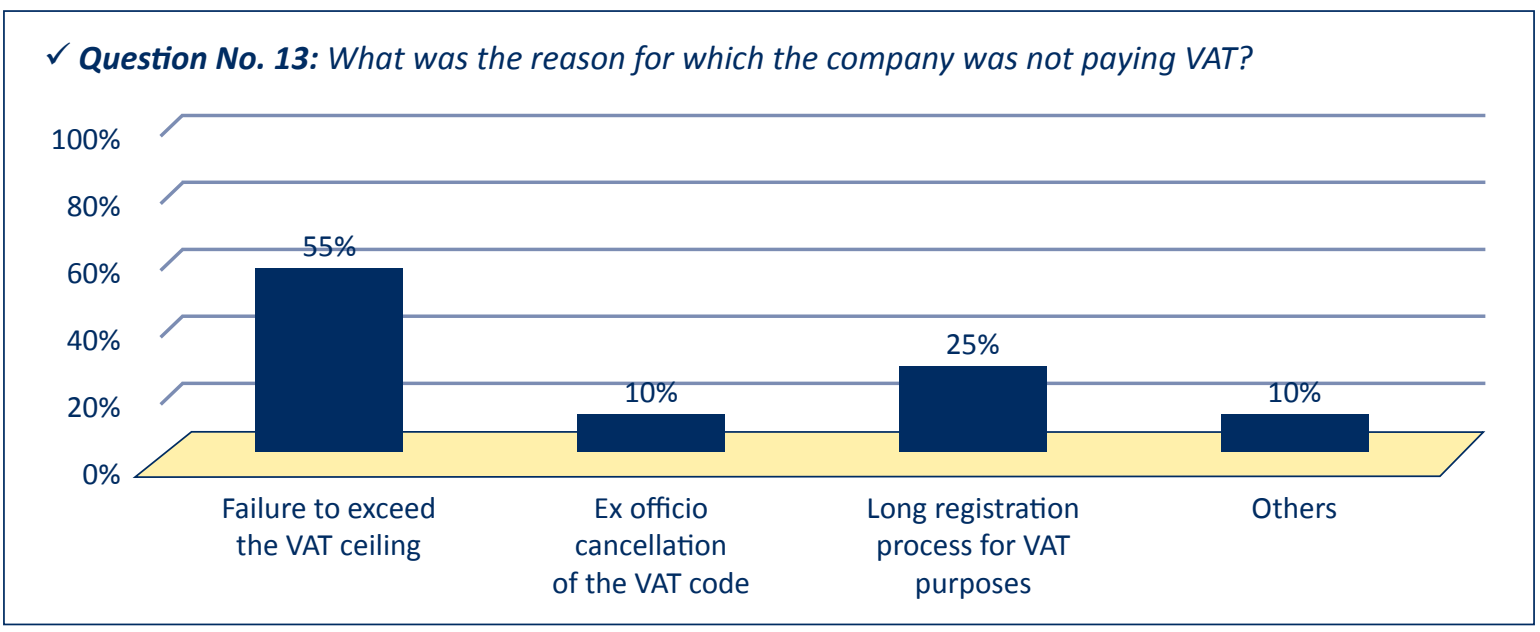

Figure 9. Companies not paying VAT

Of the $28.3 \%$ respondents who stated that they were in a situation where the company they work for or run was not a VAT payer, $55 \%$ was due to the fact that the VAT threshold was not exceeded (100,000 EUR). The long process of registration for VAT purposes represented the reason of $25 \%$ of the respondents, and $10 \%$ stated the reason was due to the ex officio cancellation of the VAT code (expired registered office, failure to submit VAT returns for a period of time etc.). Also, $10 \%$ of respondents were in this situation due to the fact that the company in question was newly established and the lengthy VAT registration process had to be taken into account. 


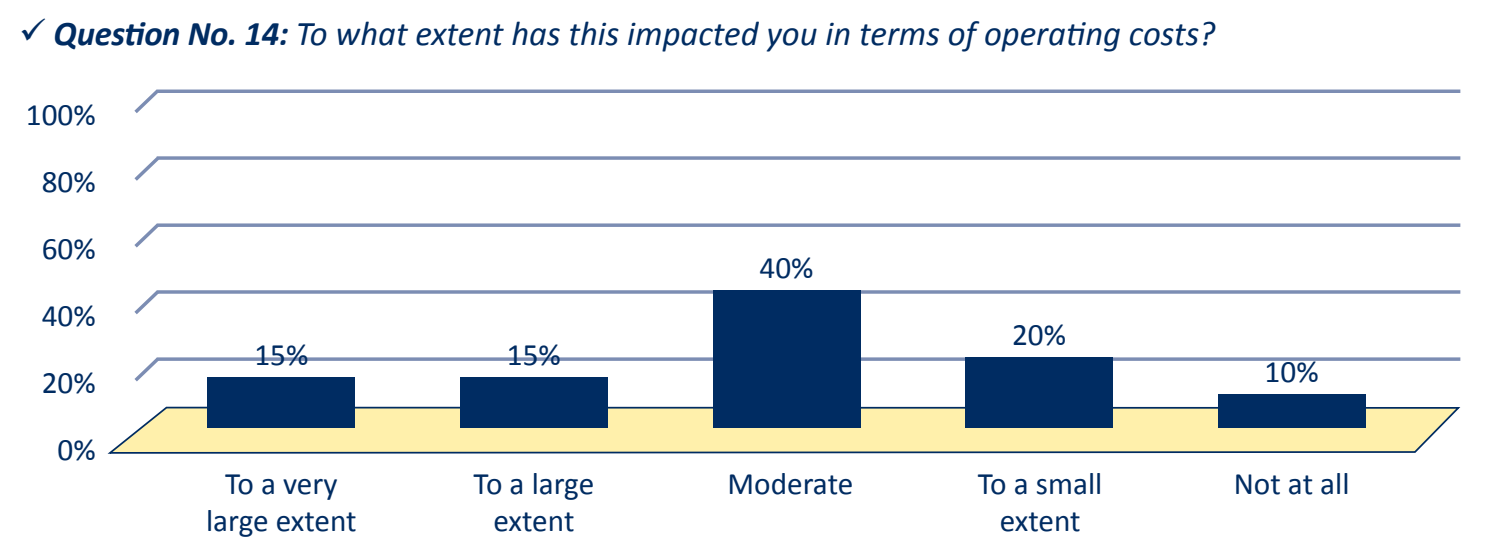

Figure 10. Impact on operating costs

According to the graph above, the non-registration of a company for VAT purposes had a small impact on economic activity in terms of operating costs in the medium term ( $40 \%$ of respondents).

$\checkmark$ Question No. 15: Are you familiar with the notion of VAT cash accounting system?

Following the answers of the 60 respondents, we discovered that most of them (98.3\%) are familiar with the notion of VAT cash accounting system.

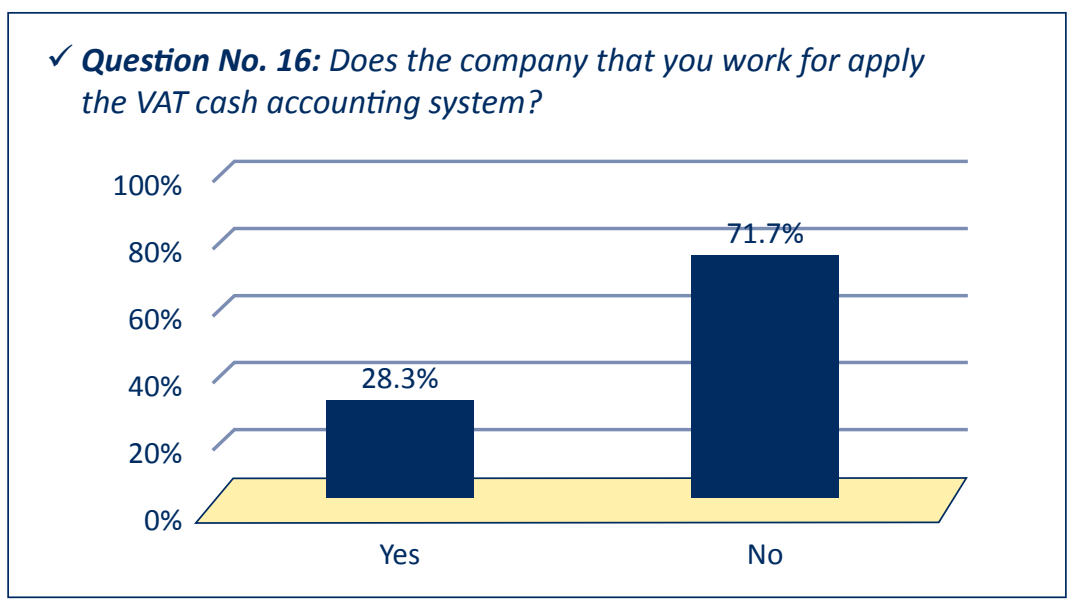

Figure 11. VAT cash accounting system application

From the results obtained from the survey, a percentage of $71.7 \%$ stated that the VAT cash accounting system is not applied in the company that they work for.

$\checkmark$ Question No. 17: Do you consider the application of the VAT cash accounting system to be beneficial to the economic activity of the company that you work for?

Out of the $28.3 \%$ of respondents whose companies apply this system of VAT on collection, $94.1 \%$ said it is beneficial to economic activity. By applying the VAT cash accounting system, companies thus benefit from the postponement of the payment of the tax to the state budget.

\section{Conclusions}

Following the completion of this paper, we can conclude that the changes taking place at the national level are quite numerous and mainly influence the operational activities of entrepreneurs. 
We consider that the value added tax is a topical issue, which also generates various problems, putting practitioners in difficulty. For this reason, we have chosen to carry out a quantitative research based mainly on the experiences of taxpayers, who have encountered problems with the legislative changes on VAT, as well as their opinion on the many changes.

In the research conducted, through the stratified questionnaire, we can conclude that changes in VAT legislation impact the economic activities of entrepreneurs to some extent. The biggest impact that these changes generate mainly relates to the additional costs incurred in updating the accounting systems used. Thus, the following positive aspects of the legislative changes on the economic environment can be determined as follows:

- stimulating the consumption of products/services by decreasing the selling prices;

- better standard of living, due to the increased consumption of goods and services;

- decreasing the level of taxes paid to the state;

- attractive environment for foreign investors.

Of course, the negative effects are not missing from this equation, therefore, according to the results obtained from the research, we determined that the possibility of non-deductibility of value added tax and additional costs generated by updating accounting programs and software used has the highest preponderance. Unfortunately, we believe that these negative effects cannot be combated and no solutions can be found due to the fact that the period in which the changes occur cannot be determined in advance.

The approach adopted in the situations presented above would consist in the development of fiscal and legislative knowledge on VAT, knowledge that can be applied during the development of economic activity. Thus, entrepreneurs should focus more on developing and capitalizing on their potential and resources. We believe that the value added tax should be reduced, so that the tax burden can be reduced, which would also lead to lower costs and selling prices. At the same time, by reducing taxes and direct taxes, certain activities would be stimulated. The biggest impact following the legislative changes related to VAT is felt especially on people with low incomes. Taking into account the fact that this tax is usually levied on the sale of products, it is borne by the final consumer, by including it in the selling price.

In order to eliminate the negative effects, we recommend that the interaction with the information systems of tax consultants be improved. At the same time, we believe that the offering an ample presentation of the tax legislation and deepening it by creating a welcoming framework through an information assistance center could contribute to the reduction of costs related to subscriptions with the tax consultants. On the other hand, if we analyze the situation from the point of view of the state budget, we could conclude that if the procedure for canceling the VAT registration of taxpayers were improved, the fraudulent actions would be reduced. In order for economic operators to be aware of their tax status, we recommend that the existing database be constantly updated. This can determine the state of affairs of taxpayers.

In other words, if the taxpayer verification systems were constantly improved and updated, tax evasion and cascading taxes would be at a lower level and the collection of arrears would be more efficient.

\section{References}

1. Stanciu, G.-A. (2020), National and International Fiscal Regulations on Value Added Tax (I), CECCAR Business Review, No. 10, pp. 61-72, http://dx.doi.org/10.37945/cbr.2020.10.08.

2. Stanciu, G.-A. (2020), National and International Fiscal Regulations on Value Added Tax (II), CECCAR Business Review, No. 11, pp. 64-72, http://dx.doi.org/10.37945/cbr.2020.11.08.

3. Minister of Finance, Sisteme de impozitare în Uniunea Europeană, http://discutii.mfinante.ro/static/10/ $\mathrm{Mfp} /$ trezorerie/sisteme_imp_UE_directe_indir_contributii.pdf.

4. http://www.isondaje.ro/

5. https://www.europa.eu/ 